\title{
The Glycation Products Before and After Therapy for Acute and Chronic Pain
}

\section{R. ROKYTA ${ }^{1}$, J. LEJČKO ${ }^{2}$, K. HOUDEK ${ }^{3}$, L. TREFIL ${ }^{4}$, J. NEDVÍDEK ${ }^{5}$, J. FRICOVÁ ${ }^{6}$, V. HOLEČEK ${ }^{1}$}

${ }^{1}$ Department of Normal, Pathological and Clinical Physiology, Third Faculty of Medicine, Charles University, Prague, Czech Republic, ${ }^{2}$ Department of Anesthesiology, Resuscitation and Intensive Medicine, Pain Management Centre, Faculty of Medicine and University Hospital, Charles University, Plzeň, Czech Republic, ${ }^{3}$ Department of Surgery, Faculty of Medicine and University Hospital, Charles University, Plzeň, Czech Republic, ${ }^{4}$ Department of Clinical Biochemistry and Hematology, Charles University, Plzeň, Czech Republic, ${ }^{5}$ Department of Anesthesiology, Resuscitation and Intensive Medicine, Pain Management Centre, Charles University, First Faculty of Medicine and General University Hospital, Prague, Czech Republic, ${ }^{6}$ Department of Clinical Biochemistry, Mulač Hospital, Plzeň, Czech Republic

Received July 4, 2018

Accepted November 13, 2018

\section{Summary}

Pain increased the number of free radicals in the body. Previously, we studied changes mainly in oxygen and nitroxide free radicals and described these changes relative to the lipids and saccharides. In this article we focus on changes relative to proteins. Assessment of AGE products (advanced glycation end-products) was carried out by measuring fluorescence. Patients were divided into two groups: 15 patients with acute pain and 17 patients with chronic pain. Acute pain was associated with a variety of surgical procedures and patients were examined before and after surgical procedures. The group of patients with chronic pain suffered from various types of chronic pain, but mainly back pain. In patients with acute pain, total protein (TP) decreased after surgery, as did the level of AGE and the AGE/TP ratio. Nonetheless, post-operative pain increased. In patients with chronic pain, neither total protein, AGE, or AGE/TP changed, despite significant pain relief being reported after treatment. Changes in proteins, as biochemical markers, before and after pain treatment did not show any significant changes. In patients with acute pain, the recorded changes only lasted for 3-5 days after the operation. While in chronic pain, there were no significant changes at all. The assumption that changes in proteins, as biomarkers, would have the same importance as changes in lipids and saccharides was not proven.

\section{Key words}

Acute $\bullet$ Chronic pain $\bullet$ Glycation $\bullet$ Fluorescence

\section{Corresponding author}

R. Rokyta, Department of Normal, Pathological and Clinical Physiology, Third Faculty of Medicine, Charles University, Ke Karlovu 4, 120 00, Prague 2, Czech Republic. E-mail: richard.rokyta@lf3.cuni.cz

\section{Introduction}

Pain produces elevated levels of free radicals in the body. Among others, they cause an increase in the level of AGE (advanced glycation end-products). Imbalances can occur when the formation of AGE exceeds their breakdown, which takes place after binding to the receptor for advanced glycation end-products (RAGE) (Kalousová et al. 2002). The level of AGE increases with the age. AGE also supports the formation of other free radicals. Additionally, antioxidant levels are also known to decrease with age. Glycated proteins AGE (advanced glycation end-products) activate AGE receptors (RAGE) and cause long term inflammation, accompanied by formation of other free radicals. RAGE (a transmembrane receptor) activation leads to the 
formation of nuclear factor kappa B (NF kappa B) and increases intracellular oxygen stress, thus it suppresses some endogenous autoregulation functions. AGE are the end-product of non-enzymatic reactions between proteins and reducing sugars (Amadori and Schiff bases, Maillard products), most often glucose and lysine residues (Vistoli 2013). Subsequent binding to AGE receptors (RAGE) leads to a variety of physiological responses such as (1) increased vascular permeability, (2) inhibition of vascular dilatation by blocking the function of nitric oxide, (3) increased oxidation of LDL-cholesterol, (4) increased production of various cytokines, and (5) increase oxidative stress. They also accelerate oxidative damage to tissues and cells, and support coagulopathy. Serum concentrations of AGE are also significantly higher in non-diabetic patients with coronary artery disease and significantly correlated with the degree of venous stenosis. Therefore, there appears to be a relationship between AGE and the severity of coronary disease in non-diabetic patients, and based on serum AGE levels, the degree of vascular damage can be predicted (Witko-Sarsat et al. 1996, Kanauchi 2001).

Patients with fibromyalgia also have higher serum AGE levels (pentosidine) compared to other patients. AGE modification decreases solubility and has a high resistance to proteolytic digestion. AGE, via RAGE, stimulate cells by activation of NF kappa B, thus contributing to the formation, duration, and radiation of pain in patients with fibromyalgia (Hein and Franke 2002).

Assessment of AGE before and after acute and chronic pain treatment could be useful in evaluating pain intensity and effectiveness of treatment; this was shown by our previous experimental (Rokyta et al. 2008, Rokyta et al. 2004) and clinical work (Fricová et al. 2010, Rokyta et al. 2009, Krrikava et al. 2004), in which we evaluated changes in free radical concentrations, mainly oxygen and nitrogen, either by direct or spectrometric measurement (Křikava et al. 2004). We studied these changes mainly in connection with changes in lipids and glucoses. In this study, we focus mainly on changes in proteins.

\section{Methods}

Assessment of AGE was carried out by measuring fluorescence (excitation wavelength was $370 \mathrm{~nm}$, emission wavelength $440 \mathrm{~nm}$ ). Serum samples were diluted with a $\mathrm{pH} 7.4$ phosphate buffer before measuring. Results are stated in FU (fluorescence units). Measurements were made with a Cary Elipse Fluorescence Spectrophotometer Varian at Chrompack International BV (Herculesweg 8, 4330 EA Middelburg, Netherlands).

\section{Patients}

Patients were divided into two groups.

1) Patients with acute pain: 15 patients (6 men and 9 women). Patients with acute pain were treated with paracetamol and morphine derivatives.

Acute pain was post-surgical pain associated with the following diagnoses: umbilical hernia, its relapse and complications, inguinal hernia, appendicitis, cholecystitis, cholecystolithiasis, and varicose veins. Patients were examined before surgery and 3-5 days after surgery.

2) Patients with chronic pain: 17 patients ( 7 men and 10 women) with the following diagnoses: radiculopathy L5 and S1, low back pain, lumbar facet syndrome, pain after a fracture of the $\mathrm{T}-12$ vertebra. Chronic patients were tested with local anesthetics of bupivacaine (Marcain) and corticosteroids, and in this local anesthesia they were subjected to facet root blockades. Finally, all radiofrequency interventions with the Neuroterm device were finally performed.

Patients were not divided by age or gender. Only the origin of pain was used. We have always compared two groups of patients after arriving at the hospital and then after the treatment. As a subjective assessment of pain intensity, the visual analog scale 1-10 (VAS) was used.

In terms of acute pain, patients had pain upon arrival due to their underlying disease (hernia, appendicitis, gall bladder inflammation and gallstones) and post-operative pain. So we tested the AGE values for two types of pain.

\section{Statistical methods}

The differences between biochemical indicators (AGE) were evaluated by the paired $t$-test. Standard deviations are indicated in the appropriate figures. The Wilcoxon test was used for the evaluation of VAS results.

\section{Results}

In the acute pain group (15 patients; 6 men and 9 women), the average age was $50.67 \pm 13.56$ years. Total blood protein decreased slightly after surgery (before 
$69.48 \pm 3.92 \mathrm{~g} / 1$ vs. after $66.43 \pm 5.00 \mathrm{~g} / \mathrm{l})$, while blood AGE values decreased significantly (before $2.92 \pm 0.75 \mathrm{FU}$ vs. after $2.43 \pm 0.77 \mathrm{FU}$ ) (Fig. 1). The AGE/TP also decreased (before $42.02 \pm 10.39$ vs. after $36.31 \pm 10.06)$ following treatment. The measurement of VAS before and after the acute pain (Fig. 2).

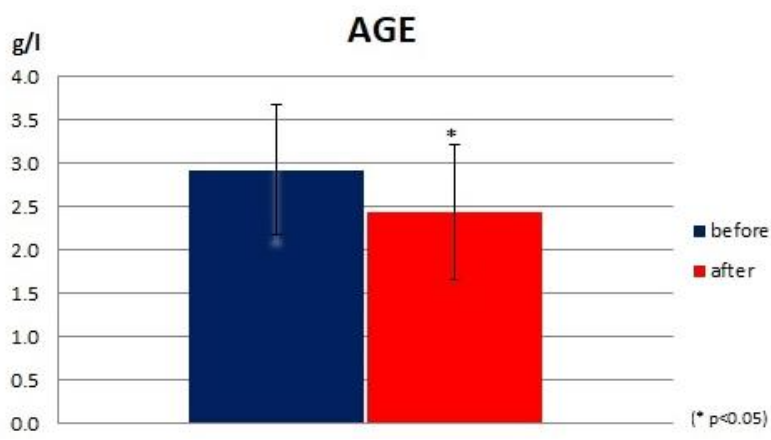

Fig. 1. The level of AGE before and after the surgical operation.

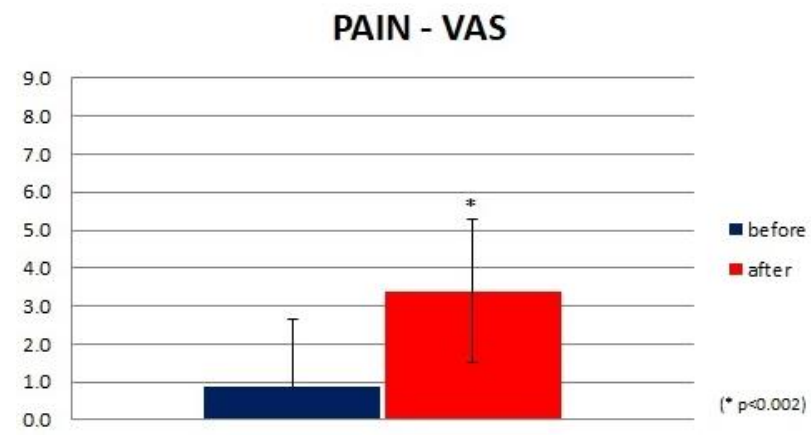

Fig. 2. The measurement of VAS before and after the acute pain.

In the chronic pain group (17 patients; 7 men, 10 women) the average age was $63.82 \pm 11.08$. Total blood protein, before and after treatment, remained almost unchanged (before $68.34 \pm 4.09 \mathrm{~g} / \mathrm{l}$ vs. after $68.77 \pm 3.53 \mathrm{~g} / \mathrm{l})$. AGE did not significantly change (before 3.16 $\pm 0.52 \mathrm{FU}$ vs. after $3.16 \pm 0.54 \mathrm{FU}$ ) (Fig. 3). The change in AGE/PT was also not significant (before $46.33 \pm 7.53$ vs. after $46.14 \pm 8.87$ ). VAS changes before and after the treatment of chronic pain (Fig. 4).

From the results stated above, it is possible to conclude that relatively younger patients with acute pain have higher antioxidative capacity as well as initial AGE levels. Pain causing formation of free radicals lasted for a shorter time, higher level of AGE producing free radicals was also elevated for a shorter time and success of the therapy was higher compared to the group of patients with a chronic pain where changes had a more long-term character.

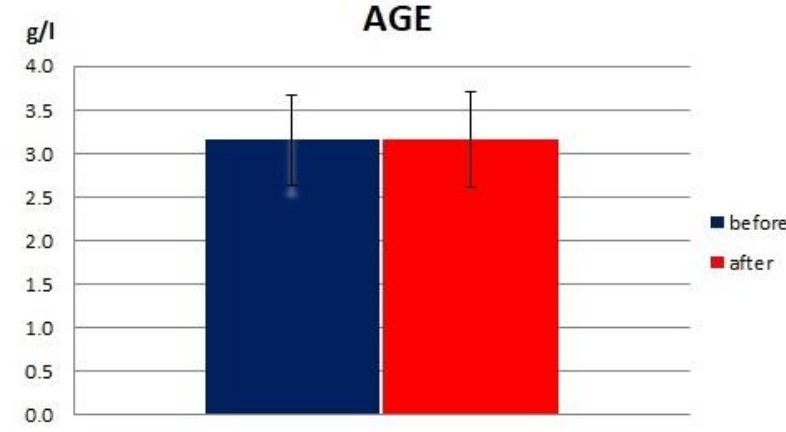

Fig. 3. AGE in chronic pain before and after the treatment.

PAIN - VAS

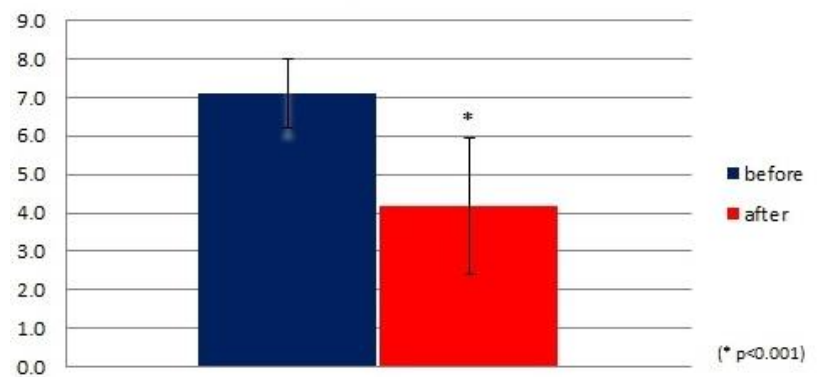

Fig. 4. VAS changes before and after the treatment of chronic pain.

\section{Discussion}

In patients with an acute post-operative pain the level of total protein, AGE, and AGE/TP decreased and post-operative pain worsened.

In patients with chronic pain total protein, AGE, AGE/TP was unchanged. Significant pain relief was observed after treatment.

Free oxygen and nitrogen radicals appear not only in pain but also in multiple sclerosis (Holeček and Rokyta 2018) and can also indicate changes in melatonin (Mareš et al.2013).

Oxidative stress and inflammation in these diseases appear in cycles.

Acute pain was primarily associated with lower AGE, which was probably caused by acute pain.

Our results show that treatment of acute pain using pain killers does not affect AGE changes before and after surgery.

\section{Conclusions}

Protein, as biochemical markers, were accessed before and after treatment for acute pain did not show significant changes. In the acute pain group, 
measurements were taken 3-5 days after the surgical procedure. The same was true for the chronic pain group that is there were no significant changes. Based on our results, we concluded that changes in protein, as a biochemical marker, would not be as useful as these changes in lipids and saccharides. Nevertheless, pain intensity was different.

From previous and current findings, we can conclude that pain intensity is different for acute and chronic pain and that AGE is not a significant marker of these changes, such as free oxygen and nitroxide radicals and glucose values.

\section{Conflict of Interest}

There is no conflict of interest.

\section{Acknowledgements}

The paper was supported by: Charles University grant "Progress Q 35" and Agency of Health Research of the Ministry of Health grant "AZV 15-31538 A."

\section{References}

FRICOVA J, STOPKA P, KRIZOVA J, YAMAMOTOVA A, ROKYTA R: The effect of laparotomy on hydroxyl radicals, singlet oxygen and antioxidants measured by EPR method in the tails of rats. Neuro Endocrinol Lett 30: 373-376, 2009.

FRICOVA J, VEJRAŽKA M, STOPKA P, KRIZOVA J, BĚLÁČEK J, ROKYTA R: The influence of pre-emptive analgesia on postoperative analgesia and its objective evaluation. Arch Med Sci 6: 764-771, 2010.

HEIN G, FRANKE S: Are advanced glycation end-product-modified proteins of pathogenetic importance in fibromyalgia? Rheumatology (Oxford) 41: 1163-1167, 2002.

HOLECEK V, ROKYTA R: Possible etiology and treatment of amyotrophic lateral sclerosis. Review. Neuro Endocrinol Lett 38: 528-531, 2018.

KALOUSOVÁ M, SKRHA J, ZIMA T: Determination of advanced glycation end-products (AGE) and advanced oxidation protein products. Klin Biochem Metab 10: 11-16, 2002.

KANAUCHI M, TSUJIMOTO N, HASHIMOTO T: Advanced glycation end products in nondiabetic patients with coronary artery disease. Diabetes Care 24: 1620-1623, 2001.

KRIKAVA K, KALLA K, YAMAMOTOVÁ A, ROKYTA R: Blood serum changes in patients with pain during bone fractures and acute pancreatitis. Neuro Endocrinol Lett 25: 62-69, 2004.

MAREŠ J, STOPKA P, NOHEJLOVÁ K, ROKYTA R: Oxidative stress induced by epileptic seizure and its attenuation by melatonin. Physiol Res 62 (Suppl 1): 67-74, 2013.

ROKYTA R, STOPKA P, HOLECEK V, KRIKAVA K, PEKÁRKOVÁ I: Direct measurement of free radicals in the brain cortex and the blood serum after nociceptive stimulation in rats. Neuro Endocrinol Lett 25: 252-256, 2004.

ROKYTA R, HAKLOVA O, YAMAMOTOVA A: Assessment of chronic benign and cancer pain using blood plasma biomarkers. Neuro Endocrinol Lett 30: 637-642, 2009.

ROKYTA R, STOPKA P, KAFUNKOVA E, KRIZOVA J, FRICOVA J, HOLECEK V: The evaluation of nociceptive intensity by using free radicals direct measurement by EPR method in the tail of anaesthetized rats. Neuro Endocrinol Lett 29: 1007-1014, 2008.

VISTOLI, G, DE MADDIS D, CIPAK A, ZARKOVIC N, CARINI M, ALDINI G: Advanced glycoxidation and lipoxidation end products (AGEs and ALEs): an overview of their mechanisms of formation. Free Radic Res 47 (Suppl 1): 3-27, 2013.

WITKO-SARSAT V, FRIEDLANDER M, CAPEILLÈRE-BLANDIN C, NGUYEN-KHOA T, NGUYEN AT, ZINGRAFF J, JUNGERS P, DESCAMPS-LATSCHA B: Advanced oxidation protein products as a novel marker of oxidative stress in uraemia. Kidney Int 49: 1303-1313, 1996. 